\title{
BRAZILIAN LANDSCAPE STYLES AND TREE BIODIVERSITY IN PUBLIC GARDEN SQUARES
}

\author{
Jennifer Viezzer ${ }^{*}$, Daniela Biondi ${ }^{2}$, Antonio Carlos Batista ${ }^{2}$, Angeline Martini $^{3}$, Emidio Neves de Moraes $^{4}$ \\ 1* Federal University of Paraná, Graduate Program in Forest Engineering, Curitiba, Paraná, Brazil - jen.viezzer@gmail.com \\ ${ }^{2}$ Federal University of Paraná, Department of Forest Sciences, Curitiba, Paraná, Brazil - dbiondi@ufpr.br; batistaufpr@ufpr.br \\ ${ }^{3}$ Federal University of Viçosa, Department of Forest Engineering, Viçosa, Minas Gerais, Brazil - martini.angeline@gmail.com \\ ${ }^{4}$ Federal University of Paraná, Forest Engineer, Curitiba, Paraná, Brazil - emidio.neves.moraes@gmail.com
}

Received for publication: 12/12/2018 - Accepted for publication: 09/05/2019

\begin{abstract}
Resumo
Linhas projetuais paisagísticas brasileiras e a biodiversidade arbórea em praças. As principais características da linha paisagística contemporânea são a recuperação de áreas degradadas e o uso de espécies nativas. O objetivo desta pesquisa foi analisar a vegetação das praças de Curitiba-PR para verificar se as áreas criadas no período da linha contemporânea (a partir de 1990) têm maior diversidade de espécies arbóreas se comparadas às demais praças e, assim, são mais significativas para a conservação da biodiversidade. Para isso, foi realizado um cálculo estatístico que determinou a amostragem de 32 das 454 praças da cidade, que então foram classificadas por ano de criação e linha paisagística. As árvores foram identificadas quanto a espécie e família, e sua origem foi definida. As variáveis analisadas foram: riqueza; média de espécies; número de indivíduos; densidade de indivíduos; e os índices de Shannon, Pielou, e Odum. As 15 praças da linha contemporânea apresentaram 399 indivíduos de 54 espécies e 27 famílias, sendo exóticos 43,61\% dos indivíduos e 50,00\% das espécies; média de indivíduos de $26,60 \pm 9,72$ por praça e $43,09 \pm 35,13$ por hectare; média de espécies de $6,93 \pm 4,98$ por praça e 13,95 $\pm 10,63$ por hectare; e índices de Shannon de 3,39, Pielou 0,85, e Odum 9,02. As praças da linha contemporânea apresentaram maiores índices de diversidade, porém possuem, em média, menos espécies, famílias e indivíduos, além de maior proporção de espécies e indivíduos exóticos. Esses resultados indicam que essas praças não seguiram as características típicas da linha contemporânea e não são mais significativas para a conservação da biodiversidade quando comparadas as demais praças.

Palavras-chave: arborização urbana, áreas verdes, espécies nativas, índice de Shannon, índice de Pielou.
\end{abstract}

\begin{abstract}
The main features of the Brazilian contemporary landscape style are the recovery of degraded areas and the use of indigenous species. This study aimed at analyzing the vegetation of the Curitiba-PR public garden squares to verify if the areas created during the contemporary period (from 1990 on) have a greater diversity of tree species than other squares and, therefore, are more significant for biodiversity conservation. For this, 32 of the city's 454 squares were sampled as determined by statistical calculation, then classified by creation year and landscape style. Trees species, families, and individuals were identified and classified as to their origin; and the variables richness; average species; number of individuals; density of individuals; and the Shannon, Pielou, and Odum indexes were analyzed. The 15 contemporary style squares presented 399 individuals of 54 species and 27 families, with $43.61 \%$ of the individuals and $50.00 \%$ of the species of exotic origin; individuals average of $26.60 \pm 9.72$ per square and $43.09 \pm 35.13$ per hectare; species average of $6.93 \pm 4.98$ per square and $13.95 \pm 10.63$ per hectare; and diversity indexes of Shannon 3.39, Pielou 0.85, and Odum 9.02. The squares in the contemporary style presented higher diversity indexes, but they have, on average, fewer species, families, and individuals, in addition to a greater proportion of exotic species and individuals. These results indicate that these squares did not follow the typical characteristics of the contemporary style and are of no greater significance for biodiversity conservation when compared to other squares.

Keywords: urban forest, green areas, indigenous species, Shannon diversity index, Pielou diversity index.
\end{abstract}

\section{INTRODUCTION}

The public green areas in Brazilian cities can be classified in three landscape styles - eclectic, modern, and contemporary; presenting distinct characteristics to urban spaces such as parks and garden squares (ROBBA; MACEDO, 2010).

The first garden squares in Brazil followed European landscape design trends, which used to represent nature dominated by humans, highlighting symmetry and geometry, and valuing focal points through the use of statues, monuments, and fountains (MAGALHÃES, 2014; SILVA, 2014). The inauguration of Rio de Janeiro Passeio Público park in 1783 was a milestone for the Brazilian eclectic landscape style that, besides the already mentioned attributes imported from Europe, is determined by the soil impermeabilization and by exotic species to the Brazilian flora (ROBBA; MACEDO, 2010; OLIVEIRA et al., 2013; SILVA, 2014).

From 1930 on, the first signs of change appeared in the conception of green areas in the cities through the country, especially the work done by Roberto Burle Marx, who started a trend of valorizing the Brazilian native

FLORESTA, Curitiba, PR, v. 50, n. 3, p. 1510 - 1517, jul/set 2020.

Viezzer, J. et.al.

ISSN eletrônico 1982-4688

DOI: $10.5380 /$ rf.v50 i3. 63862 
vegetation and became the symbol of the modern landscape style (OLIVEIRA et al., 2013; CARNEIRO, 2014). Starting in 1934, with the Casa Forte garden square by Burle Marx, in Recife-PE, the modern landscape style began to employ indigenous species and highlighted the Brazilian vegetation, using it as inspiration for the use of shapes, colors and textures (CARNEIRO, 2014; SILVA, 2014).

The emergence of the contemporary landscape style in 1990, with the inauguration of the Pedreiras park, in Curitiba-PR, coincided with the advancement of the Brazilian environmental policy and awareness about the importance of nature conservation in the country (ROBBA; MACEDO, 2010; GENGO; HENKES, 2012). This style presents the reconciliation between the public and social use of urban green areas, as well as the recovery of native vegetation and degraded areas as main characteristics. The contemporary style, therefore, gives importance to soil permeability and the use of indigenous species to the local ecosystem.

The transformation that occurred with the evolution of the Brazilian landscape styles over time increased expressiveness of the green areas. While they already presented a relevant position of public use and sociability, in addition to sanitary and hygienist importance from the eclectic style period, green areas became strategic and indispensable for biodiversity conservation and ecosystem services provision, essential to the people in the current urban context.

The frequency of garden squares implementation in Curitiba-PR follows an increasing trend over time, following the advance of awareness on the importance of these green areas for the city. However, there is no information on whether this increment on the number of garden squares represents a gain for biodiversity conservation in the city, nor if the garden squares of Curitiba evolved according to the main characteristics of the dominant landscape style of its creation year. Thus, this study sought to verify whether the garden squares created at the time of the contemporary landscape style (from 1990 until now) have a greater diversity of tree species and, thus, are more significant for biodiversity conservation when compared to the other squares. Bearing this in mind, the objective of this study was to analyze the trees in Curitiba garden squares by the dominant landscape style of its creation year.

\section{MATERIAL AND METHODS}

As shown in Figure 1, Curitiba is the capital of Paraná state, located in the Southern region of Brazil, at $25^{\circ} 25^{\prime} 48^{\prime \prime} \mathrm{S}$ and $49^{\circ} 16^{\prime} 15^{\prime} \mathrm{W}$ (CURITIBA, 2018). It has an area of $435.036 \mathrm{~km}^{2}$, with 1,917,185 inhabitants and a population density of 4,406.96 inhabitants per $\mathrm{km}^{2}$ (INSTITUTO BRASILEIRO DE GEOGRAFIA E ESTATÍSTICA - IBGE, 2018). The municipality is in the Atlantic Forest Biome, in the ecosystem of the Mixed Ombrophilous Forest, known as Araucaria Forest (BRASIL, 2006; IBGE, 2018). It has $58 \mathrm{~m}^{2}$ of green area per inhabitant, with 454 public garden squares among its 1,106 green areas (CURITIBA, 2018).

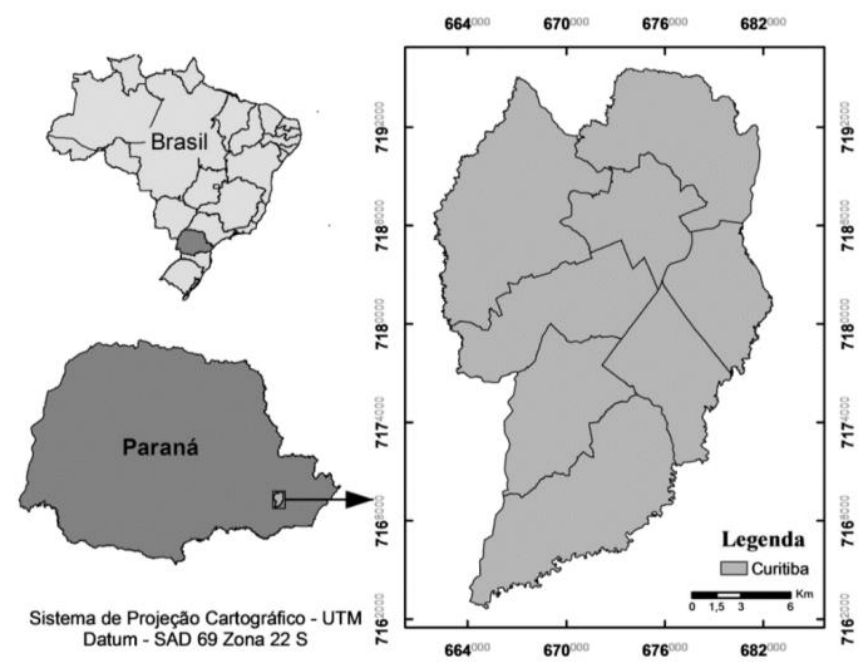

Figure 1. Geographic location of Curitiba, Paraná, Brazil (adapted from IBGE, 2018).

Figura 1. Localização geográfica da cidade de Curitiba, Paraná, Brasil (adaptado de IBGE, 2018).

To analyze the trees present in the garden squares of Curitiba according to the dominant landscape style of its creation year, the population to be considered in this research was determined using two criteria: having a name and a date of creation. Considering that there are 454 public garden squares in Curitiba, 343 of them have a name, 101 have dates of creation registered by the Municipal Environment Bureau, and 56 squares have dates found

FLORESTA, Curitiba, PR, v. 50, n. 3, p. 1510 - 1517, jul/set 2020

Viezzer, J. et.al.

ISSN eletrônico 1982-4688

DOI: $10.5380 /$ rf.v50 i3. 63862 
in documents of the House of Memory of Curitiba archives. With this, a total population of 157 squares was established.

For the execution of a pilot study, $10 \%$ of the squares were drawn using the random sampling method, in which the proportion of permeable area in relation to the total area of the squares was obtained as a variable of interest. This variable was chosen because it is representative of the landscape styles as the eclectic style is characterized by having a smaller permeable area, the contemporary style for having a larger permeable area, and the modern style for being intermediate to the others (VIEZZER et al., 2016). The permeable and total areas were measured in the squares with the support of a field team usually composed by three researchers, and equipment such as clipboard, pencil, and measuring tape. The Google Earth Pro area measurement tool was used for cartographic support. The pilot study allowed the calculation of the number of samples required for the study, considering $90 \%$ of confidence level for an error limit of $15 \%$, by through the equation for finite population, as presented below.

$$
\begin{gathered}
E^{2}=(E L * \bar{X})^{2} \\
n=\frac{s^{2} t^{2}}{E^{2}+\left(\frac{s^{2} t^{2}}{N}\right)}
\end{gathered}
$$

where: $\mathrm{E}^{2}=$ permissible error around the average; $\mathrm{LE}=$ error limit; $\bar{X}=$ estimated mean; $\mathrm{n}=$ sample size; $\mathrm{s}^{2}=$ variance of the variable of interest; $t=$ tabled value of the " $t$ " Student; $N=$ population size.

The calculation of the adequate amount of garden squares to be sampled so that the result would be considered significant resulted in 32 squares. Therefore, 16 more squares were randomly drawn and added to the squares of the pilot study, reaching $20.40 \%$ of the population surveyed. Of the 32 squares selected, four were created between 1783 and 1933, when the eclectic landscape style was predominant $(26.67 \%$ of the total squares in this style); 13 between 1934 and 1989, at the time of the modern landscape style (19.12\% of the total squares in this style); and 15 from 1990 until now, at the time of the contemporary landscape style $(20.38 \%$ of the total squares in this style), as presented in Table 1.

Table 1. List of sampled garden squares.

Tabela 1. Lista das praças amostradas.

\begin{tabular}{llcc}
\hline $\mathbf{N}^{\mathbf{0}}$ & \multicolumn{1}{c}{ GARDEN SQUARES } & CREATION YEAR & LANDSCAPE STYLE \\
\hline 1. & Tiradentes & 1880 & Eclectic \\
2. & Carlos Gomes & 1890 & Eclectic \\
3. & José Borges de Macedo & 1898 & Eclectic \\
4. & Santos Andrade & 1901 & Eclectic \\
\hline 5. & Garibaldi & 1946 & Modern \\
6. & do Redentor & 1953 & Modern \\
7. & da Espanha & 1955 & Modern \\
8. & Pe. João Bagozzi & 1961 & Modern \\
9. & Alfredo Andersen & 1969 & Modern \\
10. & Villa Lobos & 1970 & Modern \\
11. & Abílio de Abreu & 1974 & Modern \\
12. & Itália & 1975 & Modern \\
13. & Isaac Milder & 1976 & Modern \\
14. & Presidente Eisenhower & 1977 & Modern \\
15. & Tobias Bueno Arruda & 1978 & Modern \\
16. & Francisco R. A. de Macedo & 1980 & Modern \\
17. & Nova República & 1985 & Contemporary \\
\hline 18. & Lúcia Bozza Pilatti & 1991 & Contemporary \\
19. & Piazza San Marco & 1992 & Contemporary \\
20. & Pe. Agostinho Legros & 1992 & Contemporary \\
21. & do Japão & 1993 & Contemporary \\
22. & Vívian Calopreso Braga & 1994 & Contemporary \\
23. & Nelson Monteiro & 1994 & Contemporary \\
24. & Rio Iguaçu & 1994 & Contemporary \\
25. & Pe. Dario Zampiero & 1995 & Contemporary \\
26. & Profa. Rosa Kolody & 1997 & \\
27. & da Colonização Menonita & 2000 &
\end{tabular}

FLORESTA, Curitiba, PR, v. 50, n. 3, p. 1510 - 1517, jul/set 2020.

Viezzer, J. et.al.

ISSN eletrônico 1982-4688

DOI: 10.5380/rf.v50 i3. 63862 


\begin{tabular}{llll} 
28. & Irene Pereira e Silva & 2000 & Contemporary \\
29. & Loris Scorsin & 2000 & Contemporary \\
30. & Emirados Árabes Unidos & 2001 & Contemporary \\
31. Domingas Bianco Stoco & 2009 & Contemporary \\
32. & Prof. Dr. Manoel Lourenço Branco & 2012 & Contemporary \\
\hline
\end{tabular}

The trees used in the landscaping of the 32 squares were identified by family, genus, and species; origin (as exotic, indigenous to Brazil, or indigenous to Curitiba); number of individuals; and squares of occurrence. Data collection was performed in 2013. The data were transferred to spreadsheets in Microsoft Office Excel 2016 and were subsequently processed and analyzed in tables format.

To assess diversity, richness (number of species); average species per square and hectare; individual density per square and hectare; and the indexes of Shannon, Pielou, and Odum were calculated; both by landscape style and in total.

The average number of species per square and hectare, the density of individuals per square and hectare were calculated according to the equations below.

$$
\begin{array}{ll}
\bar{S}_{P}=\frac{\sum S_{p}}{P} & \bar{S}_{A}=\frac{\sum \frac{S_{p}}{a}}{P} \\
\bar{D}_{P}=\frac{\sum n_{p}}{P} & \bar{D}_{A}=\frac{\sum \frac{n_{p}}{a}}{P}
\end{array}
$$

where: $\bar{S}_{P}=$ average species per square; $\mathrm{S}_{\mathrm{p}}=$ number of species in each square; $\mathrm{P}=$ number of squares; $\bar{S}_{A}=$ average species per hectare; $\mathrm{a}=$ area of each square in hectares; $\bar{D}_{P}=$ density of individuals per square; $\mathrm{n}_{\mathrm{p}}=$ number of individuals in each square; $\bar{D}_{A}=$ density of individuals per hectare.

Being often used in ecology, the Shannon index combines richness and abundance to characterize diversity, and represents uncertainty about an individual species, as shown in the equation below (MORRIS et al.,2014).

$$
\begin{gathered}
p_{i}=\frac{n_{i}}{N} \\
H^{\prime}=-\sum_{i=1}^{S} p_{i} * \ln p_{i}
\end{gathered}
$$

where: $\mathrm{p}_{\mathrm{i}}=$ relative abundance of species $i ; \mathrm{n}_{\mathrm{i}}=$ number of individuals of species $i ; \mathrm{N}=$ total number of individuals evaluated; $\mathrm{H}^{\prime}=$ Shannon index.

The Pielou index evaluates uniformity through the pattern of distribution of individuals among species, expressed from 0 (minimum uniformity) to 1 (maximum uniformity), according to the equation below (MORRIS et al., 2014).

$$
J^{\prime}=\frac{H^{\prime}}{\ln S}
$$

where: J' = Pielou index; $\mathrm{H}^{\prime}=$ Shannon index; $\mathrm{S}=$ total number of species.

The Odum index, on the other hand, measures the intensity of species composition to express diversity, following the equation below (RODE et al., 2009).

$$
d 1=\frac{S}{\ln N}
$$

where: $\mathrm{d} 1$ = Odum index $\mathrm{S}=$ total number of species; $\mathrm{N}=$ total number of individuals.

All calculations were performed to help differentiate the compositions of tree species established in each garden square, to infer their adequacy regarding diversity. 


\section{RESULTS}

The landscape styles of the public garden squares of Curitiba and the number of squares sampled, area of the squares; average area per square; richness (number of species); average species per square; average species per hectare; number of individuals; density of individuals per square; density of individuals per hectare; and Shannon, Pielou and Odum indexes are all presented in Table 2.

Table 2. Tree species by landscape style inn sampled Curitiba garden squares.

Tabela 2. Espécies arbóreas por linhas paisagísticas das praças de Curitiba amostradas.

\begin{tabular}{|c|c|c|c|c|c|c|c|c|c|c|c|c|}
\hline $\mathbf{L S}$ & $\mathbf{P}$ & $\mathbf{A}$ & $\overline{\bar{A}}_{\mathbf{P}}$ & $\mathbf{S}$ & $\overline{\boldsymbol{S}}_{\mathbf{P}}$ & $\overline{\boldsymbol{S}}_{\mathrm{A}}$ & $\mathbf{N}$ & $\overline{\mathbf{D}}_{\mathbf{P}}$ & $\bar{D}_{\mathrm{A}}$ & $\mathbf{H}^{\prime}$ & $\mathrm{J}$ ' & d1 \\
\hline ECL & 4 & 3,28 & $\begin{array}{c}0,82 \\
\pm 0,33\end{array}$ & 44 & $\begin{array}{c}17,25 \\
\pm 12,82\end{array}$ & $\begin{array}{c}19,31 \\
\pm 15,04\end{array}$ & 396 & $\begin{array}{c}99,00 \\
\pm 71,30\end{array}$ & $\begin{array}{l}114,11 \\
\pm 92,43\end{array}$ & 3,10 & 0,82 & 7,36 \\
\hline MOD & 13 & 8,77 & $\begin{array}{c}0,67 \\
\pm 0,97\end{array}$ & 51 & $\begin{array}{c}9,00 \\
\pm 6,73\end{array}$ & $\begin{array}{c}23,82 \\
\pm 23,88\end{array}$ & 661 & $\begin{array}{c}50,85 \\
\pm 68,52\end{array}$ & $\begin{array}{c}89,82 \\
\pm 77,64\end{array}$ & 3,19 & 0,81 & 7,85 \\
\hline $\mathrm{CON}$ & 15 & 10,25 & $\begin{array}{c}0,68 \\
\pm 0,60\end{array}$ & 54 & $\begin{array}{c}6,93 \\
\pm 4,98 \\
\end{array}$ & $\begin{array}{c}13,95 \\
\pm 10,63\end{array}$ & 399 & $\begin{array}{c}26,60 \\
\pm 33,12 \\
\end{array}$ & $\begin{array}{c}43,09 \\
\pm 35,13\end{array}$ & 3,39 & 0,85 & 9,02 \\
\hline TOTAL & 32 & 22,30 & $\begin{array}{c}0,70 \\
\pm 0,73\end{array}$ & 84 & $\begin{array}{c}9,06 \\
\pm 7,45\end{array}$ & $\begin{array}{c}18,63 \\
\pm 17,77\end{array}$ & 1456 & $\begin{array}{l}\mathbf{4 5 , 5 0} \\
\pm 7,45\end{array}$ & $\begin{array}{r}70,95 \\
\pm 66,95\end{array}$ & 3,73 & 0,84 & 11,53 \\
\hline
\end{tabular}

Legend: $\mathrm{LS}=$ landscape styles; ECL = eclectic landscape style; MOD = modern landscape style; CON = contemporary landscape style; $\mathrm{P}=$ number of squares; $\mathrm{A}=$ area of the squares in hectares; $\bar{A}_{\mathrm{P}}=$ average area per square in hectares; $\mathrm{S}=$ richness (number of species); $\bar{S}_{\mathrm{P}}=$ average species per square; $\bar{S}_{\mathrm{A}}=$ average species per hectare; $\mathrm{N}=$ number of individuals; $\bar{D}_{\mathrm{P}}=$ density of individuals per square; $\bar{D}_{\mathrm{A}}=$ density of individuals per hectare; $\mathrm{H}^{\prime}=$ Shannon index; $\mathrm{J}^{\prime}=$ Pielou index; $\mathrm{d} 1$ = Odum index.

In addition to the number of species increasing along with the landscape styles, the variety of botanical families also increased, with 18 families in the eclectic style, 23 families in the modern style, and 27 families in the contemporary style, with a total of 33 different families in the 32 squares sampled. The average number of species per square, however, decreased during the advance of the landscape styles, which also occurred for the families, with $9.25 \pm 6.24$ families per square in the eclectic style, $6.54 \pm 4.31$ in the modern style, and $5.80 \pm 3.89$ in the contemporary style. The average species per hectare increased from the eclectic to the modern style and decreased from the modern to the contemporary style, occurring the same for the average of families per hectare, with $10.82 \pm 8.12$ in the eclectic style, $18.55 \pm 18.42$ in the modern style, and $12.27 \pm 9.34$ in the contemporary style.

The number of individuals in the squares increased with the passage of the eclectic to the modern landscape style, and decreased from the modern to the contemporary landscape style, although the density of individuals per square and hectare have only decreased with the advance of time. On the other hand, the Shannon and Odum indexes were lower for the eclectic style, intermediate for the modern style, and higher for the contemporary style; while the Pielou index was lower for the modern style, intermediate for the eclectic style, and higher for the contemporary style.

Regarding origin, the species and individuals were classified as exotic, indigenous to Brazil, and indigenous to Curitiba, according to Table 3.

Table 3. Origin of species and individuals by landscape style on sampled Curitiba's squares.

Tabela 3. Procedência das espécies e dos indivíduos por linhas paisagísticas das praças de Curitiba amostradas.

\begin{tabular}{ccccccccccccc}
\hline $\mathbf{L S}$ & $\mathbf{S}_{\mathbf{E}}$ & $\boldsymbol{\%} \mathbf{S}_{\mathbf{E}}$ & $\mathbf{N}_{\mathbf{E}}$ & $\boldsymbol{\%} \mathbf{N}_{\mathbf{E}}$ & $\mathbf{S}_{\mathbf{B}}$ & $\mathbf{\%} \mathbf{S}_{\mathbf{B}}$ & $\mathbf{N}_{\mathbf{B}}$ & $\mathbf{\%} \mathbf{N}_{\mathbf{B}}$ & $\mathbf{S}_{\mathbf{C}}$ & $\mathbf{\%} \mathbf{S}_{\mathbf{C}}$ & $\mathbf{N}_{\mathbf{C}}$ & $\boldsymbol{\%}_{\mathbf{C}}$ \\
\hline ECL & 16 & 36,36 & 112 & 28,28 & 16 & 36,36 & 155 & 39,14 & 12 & 27,27 & 129 & 32,58 \\
MOD & 19 & 37,25 & 255 & 38,58 & 18 & 35,29 & 176 & 26,63 & 14 & 27,45 & 230 & 34,80 \\
COM & 27 & 50,00 & 174 & 43,61 & 16 & 29,63 & 131 & 32,83 & 11 & 20,37 & 94 & 23,56 \\
\hline TOTAL & $\mathbf{3 7}$ & $\mathbf{4 4 , 0 5}$ & $\mathbf{5 4 1}$ & $\mathbf{3 7 , 1 6}$ & $\mathbf{2 6}$ & $\mathbf{3 0 , 9 5}$ & $\mathbf{4 6 2}$ & $\mathbf{3 1 , 7 3}$ & $\mathbf{2 1}$ & $\mathbf{2 5 , 0 0}$ & $\mathbf{4 5 3}$ & $\mathbf{3 1 , 1 1}$
\end{tabular}

Legend: $\mathrm{LS}=$ landscape styles; $\mathrm{ECL}=$ eclectic landscape style; $\mathrm{MOD}=$ modern landscape style; $\mathrm{CON}=$ contemporary landscape style; $\mathrm{S}_{\mathrm{E}}=$ number of exotic species; $\% \mathrm{~S}_{\mathrm{E}}=$ proportion of exotic species; $\mathrm{N}_{\mathrm{E}}=$ number of individuals of exotic species; $\% \mathrm{~N}_{\mathrm{E}}=$ proportion of individuals of exotic species; $\mathrm{S}_{\mathrm{B}}=$ number of species indigenous to Brazil; $\% \mathrm{~S}_{\mathrm{B}}=$ proportion of species indigenous to Brazil; $\mathrm{N}_{\mathrm{B}}=$ number of individuals of indigenous species from Brazil; $\% \mathrm{~N}_{\mathrm{B}}=$ proportion of individuals of indigenous species from Brazil; $\mathrm{S}_{\mathrm{C}}=$ number of species indigenous to Curitiba; $\% \mathrm{~S}_{\mathrm{C}}=$ proportion of species indigenous to Curitiba; $\mathrm{N}_{\mathrm{C}}=$ number of individuals of indigenous species from Curitiba; $\% \mathrm{~N}_{\mathrm{C}}=$ proportion of individuals of indigenous species from Curitiba.

Both the proportion of exotic species and exotic individuals increased with the passage of landscape styles, being lower in the eclectic style and higher in the contemporary style. Conversely, the proportion of species indigenous to Brazil was higher in the eclectic style and lower in the contemporary style, and although the proportion of individuals indigenous to Brazil was also higher in the eclectic style, it was lower in the modern

FLORESTA, Curitiba, PR, v. 50, n. 3, p. 1510 - 1517, jul/set 2020.

Viezzer, J. et.al.

ISSN eletrônico 1982-4688

DOI: $10.5380 /$ rf.v50 i3. 63862 
style. For both species and individuals indigenous to Curitiba, the highest proportion was found in the modern style and the lowest in the contemporary style.

\section{DISCUSSION}

This study aimed at verifying whether the public garden squares of Curitiba created at the time of the contemporary landscape style have a greater diversity of tree species and, therefore, contribute more to biodiversity conservation when compared to garden squares of other landscape styles.

The squares created at the time of the contemporary landscape style presented greater richness, greater number of families, and intermediate number of individuals - smaller than the modern squares and larger than the eclectic squares. Due to the nature of the sampling performed, however, the number of squares of each landscape style was heterogeneous, with more squares of the contemporary style evaluated than squares from the other styles. Therefore, the relative values of the variables per square should be considered for the analysis of diversity. The average species per square and hectare, family per square, and individuals per square and hectare were smaller in the contemporary style than in the other squares. Only the average family per hectare was intermediate - smaller than the squares of the modern style and larger than the squares of the eclectic style. This result was not expected due to the characteristics of each landscape style, since the recovery of native vegetation and degraded areas, together with the combination of social and environmental benefits in the same public space, are what represent the contemporary style. It was expected, therefore, that this style would present more species, families, and individuals per square and hectare.

The squares in Curitiba, in general, have a great diversity of species and families (VIEZZER et al. , 2018). However, noting that the relative number of species, families, and individuals is lower in the squares created since the 1990s, becomes worrisome for biodiversity conservation and ecosystem services provision in the city, hence biodiversity and ecosystem services are correlated (BENAYAS et al., 2009). Also, the richness of tree species is associated with human health and well-being (DALLIMER . et al., 2012).

When compared to similar studies in other Brazilian cities, the values found for species and individuals per square and hectare of the contemporary style and in Curitiba as general are noted to be low. In São Gabriel$\mathrm{RS}$, there are $37.00 \pm 6.56$ species per square, $28.65 \pm 4.38$ species per hectare, $181.00 \pm 69.40$ individuals per square, and $143.34 \pm 66.74$ individuals per hectare (OLIVEIRA-NEVES et al., 2016); in Guarapuava-PR, there are $30.80 \pm 13.55$ species per square, $163.30 \pm 96.70$ individuals per square, and $102.33 \pm 54.95$ individuals per hectare (KRAMER; KRUPEK, 2012); in Leme-SP, there are $25.00 \pm 16.09$ species per square, and $98.67 \pm 72.13$ individuals per square (TISCHER et al., 2014); and in Nova Xavantina-MT, there are $15.17 \pm 10.95$ species per square and $68.91 \pm 39.86$ individuals per square (LIMA et al., 2015).

On the other hand, the diversity indexes of Shannon, Pielou, and Odum were higher in the squares of the contemporary landscape style than in the squares of the modern and eclectic style. This occurred because, as well as the values of richness and total number of individuals, these indexes represent the total diversity, without considering the number of different squares sampled in each landscape style. Therefore, the fact that the calculation of the sample was performed taking into account the total population of squares and not the number of squares per landscape style was a limitation of this research, although it was necessary due to the lack of knowledge about the dates of creation of the squares at that time.

Nevertheless, the Shannon, Pielou, and Odum indexes found were higher than the values calculated for squares in similar studies, such as $\mathrm{H}^{\prime}=2.75$ in Caxias-MA; $\mathrm{J}^{\prime}=0.80$ in Guarapuava-PR; and $\mathrm{d} 1=2.72$ in Paragominas-PA (KRAMER; KRUPEK, 2012; COSTA et al., 2017; SILVA et al., 2018). The Shannon index of the contemporary squares was higher than that found for the street trees in Curitiba $\left(\mathrm{H}^{\prime}=3.24\right)$, although the Odum index was lower $(\mathrm{d} 1=14.56)$ (BOBROWSKI; BIONDI, 2015). The Pielou index of the contemporary style squares was also higher than that found in five parks in Curitiba $\left(\mathrm{J}^{\prime}=0.05 ; 0.06 ; 0.08 ; 0.09 ; 0.10\right)$ (BIONDI; BOBROWSKI, 2014).

As for the origin of the species, the results found were also not expected. Due to its main characteristics, it was expected to find more exotic species in the eclectic squares, due to their European influence; more indigenous species from Brazil in modern squares, for their nationalism; and more indigenous species from Curitiba in contemporary squares, for its focus on the recovery of native vegetation of the local ecosystem. However, the results found were inverse - with the squares of the eclectic style presenting higher proportion of native species and individuals, both from Brazil and from Curitiba, and the squares of the contemporary style with higher proportion of exotic species and individuals, which does not coincide with the increase in awareness about the importance of green areas for the conservation of local ecosystems that occurred starting in the 1990s (BIONDI; MUELLER, 2013).

The proportions of exotic and indigenous species and individuals in the squares of Curitiba are part of the reality presented in similar studies, which found between $51.61 \%$ and $58.82 \%$ of indigenous species, and between

FLORESTA, Curitiba, PR, v. 50, n. 3, p. 1510 - 1517, jul/set 2020.

Viezzer, J. et.al.

ISSN eletrônico 1982-4688

DOI: $10.5380 /$ rf.v50 i3. 63862 
$40.20 \%$ and $67.45 \%$ of individuals of indigenous species (KRAMER; KRUPEK, 2012; TISCHER et al., 2014; LIMA et al., 2015; COSTA et al., 2017; SILVA et al., 2018).

In general, cities need to take advantage of biodiversity conservation opportunities because they have few free spaces to do so. Therefore, each green area should be explored in its full potential to promote environmental benefits for people (VIEZZER et al., 2018). As the most recent squares, created at the time of the contemporary style, presented fewer species per square and hectare, fewer individuals per square and hectare, and a greater proportion of exotic species and individuals, public authorities should pay greater attention to these problems during the implementation and management of the squares of Curitiba.

Moreover, studies that rescue the memory of the squares in Curitiba should be explored, mainly because they are spaces related to the identity of cities and their populations. Of the total number of squares in the city, 27.59\% do not have official nomenclature, which makes it difficult to be identified (BIONDI; LIMA NETO, 2012). The lack of registration of name and date of creation of the squares was an important limitation for this study since only 157 of the 454 squares (34.58\%) were able to compose the study population.

\section{CONCLUSIONS}

- The analysis of the trees of the public garden squares in Curitiba allowed the identification of the differences between the squares according to the dominant landscape style in their year of creation.

- The squares created during the dominance of the contemporary style, from 1990 up to now, have greater richness, and higher rates of diversity of Shannon, Pielou, and Odum than the other squares.

- However, on average, the squares of the contemporary style have fewer species and fewer individuals than the squares of the modern and eclectic styles. The squares of the contemporary style also presented higher proportion of exotic species and individuals than the other squares.

- The results indicate that the squares created in the contemporary style period did not follow the typical characteristics of this style concerning the vegetation and, therefore, are of no greater significance for biodiversity conservation when compared to the other public garden squares of Curitiba.

\section{REFERENCES}

BRASIL. Lei Federal n ${ }^{\circ} 11.428$, de 22 de dezembro de 2006. Dispõe sobre a utilização e proteção da vegetação nativa do Bioma Mata Atlântica, e dá outras providências. Diário Oficial da União, Brasília, 2006.

BENAYAS, J. M. R.; NEWTON, A. C.; DIAZ, A.; BULLOCK, J. M. Enhancement of biodiversity and ecosystem services by ecological restoration: a meta-analysis. Science, Washington, v. 325, n. 5.944, p. 1121-1124, 2009.

BIONDI, D.; LIMA NETO, E. M. Distribuição espacial e toponímia das praças de Curitiba-PR. Revista Brasileira de Arborização Urbana, Piracicaba, v. 7, n. 3, p. 31-43, 2012.

BIONDI, D.; MULLER, E.M. Espécies arbóreas invasoras no paisagismo dos parques urbanos de Curitiba-PR. Floresta, Curitiba, v. 43, p. 69-82, 2013.

BIONDI, D; BOBROWSKI, R. Utilização de índices ecológicos para análise do tratamento paisagístico arbóreo dos parques urbanos de Curitiba-PR. Enciclopédia Biosfera, Goiânia, v. 10, n. 18, p. 3006-3017, 2014.

BOBROWSKI, R.; BIONDI, D. Influência das espécies exóticas invasoras na expressão da diversidade da arborização de ruas de Curitiba-PR. Revista Brasileira de Arborização Urbana, Piracicaba, v. 10, n. 2, p. 27 39, 2015.

CARNEIRO, A. R. S. Burle Marx e os jardins do Recife. Revista Espaço Acadêmico, Maringá, v. 13, n. 156, p. 45-59, 2014.

COSTA, C. F.; FONSECA, R. S.; ALMEIDA, D. B.; OLIVEIRA, M. S.; OLIVEIRA, D. S.; BRAGA, J. H. P. Espécies utilizadas na arborização em praças do município de Caxias, Maranhão. Revista Brasileira de Arborização Urbana, Piracicaba, v. 12, n. 1, p. 65-78, 2017.

DALLIMER, M.; IRVINE, K. N.; SKINNER, A. M. J.; DAVIES, Z. G.; ROUQUETTE, J. R.; MALTBY L. L.; WARREN, P. H.; ARMSWORTH, P. R.; GASTON K. J. Biodiversity and the feel-good factor: understanding associations between self-reported human well-being and species richness. BioScience, Washington, v. 62, n. 1, p. 47-55, 2012.

GENGO, R. de C.; HENKES, J. A. A utilização do paisagismo como ferramenta na preservação e melhoria ambiental em área urbana. Gestão e Sustentabilidade Ambiental, Florianópolis, v. 1, n. 2, p. 55-81, 2012.

FLORESTA, Curitiba, PR, v. 50, n. 3, p. 1510 - 1517, jul/set 2020

Viezzer, J. et.al.

ISSN eletrônico 1982-4688

DOI: 10.5380/rf.v50 i3. 63862 
INSTITUTO BRASILEIRO DE GEOGRAFIA E ESTATÍSTICA (IBGE). Cidades: Brasil/Paraná/Curitiba. Disponível em: https://cidades.ibge.gov.br/brasil/pr/curitiba. Acesso em: 07 dez. 2018.

KRAMER, J. A.; KRUPEK, R. A. Caracterização florística e ecológica da arborização de praças públicas do município de Guarapuava, PR. Árvore, Viçosa, v. 36, n. 4, p. 647-658, 2012.

LIMA, J. P.; KREUTZ, C.; PEREIRA, O. R. Levantamento florístico das espécies utilizadas na arborização de praças no município de Nova Xavantina - MT. Revista Brasileira de Arborização Urbana, Piracicaba, v. 10, n. 3, p. 60-72, 2015.

MAGALHÃES, C. M. A arte de modelar a paisagem: os ornatos de arquitetura para jardins no ecletismo do paisagismo brasileiro. Revista Espaço Acadêmico, Maringá, v. 13, n. 156, p. 74-93, 2014.

MORRIS, E. K.; CARUSO, T.; BUSCOT, F.; FISCHER, M.; HANCOCK, C.; MAIER, T. S.; MEINERS, T.; MÜLlER, C.; OBERMAIER, E.; PRATI, D.; SOCHER, S. A.; SONNEMANN, I.; WÄSCHKE, N.; WUBET, T.; WURST, S.; RILLIG, M. C. Choosing and using diversity indices: insights for ecological applications from the German Biodiversity Exploratories. Ecology and Evolution, local, v. 4, n. 18, p. 3514-3524, 2014.

OLIVEIRA, M. D.; PERETTI, C.; BUDKE, J. C.; SANTOS, S. C. D.; CORAZZA, T.; GOMES, S.; QUADROS, F. R. D.; DECIAN, V. S.; ZANIN, M. E. Reflexos da evolução urbana sobre a arborização em Erechim, Sul do Brasil. Revista Brasileira de Arborização Urbana, Piracicaba, v. 8, n. 2, p. 86-103, 2013.

OLIVEIRA-NEVES, P.; BARBOSA JÚNIOR, A. S.; LOPES, B. S.; ANDREIS, D.; GONCALVES, E. B.; LEMOS, G. M. Diagnóstico florístico-estrutural e potencial invasor da composição arbórea de praças municipais de São Gabriel, RS, Brasil. Pesquisas, São Leopoldo, v. Botânica, n. 69, p. 227-238, 2016.

PREFEITURA MUNICIPAL DE CURITIBA. Perfil de Curitiba. Disponível em: www.curitiba.pr.gov.br/conteudo/perfil-da-cidade-de-curitiba. Acesso em: 07 dez. 2018.

ROBBA, F.; MACEDO, S. S. Praças Brasileiras. São Paulo: Coleção Quapá, 3 ed., 2010, 312 p.

RODE, R.; FIGUEIREDO FILHO, A.; GALVÃO, F.; AMARAL MACHADO, S. do. Comparação florística entre uma Floresta Ombrófila Mista e uma vegetação arbórea estabelecida sob um povoamento de Araucaria angustifolia de 60 anos. Cerne, Lavras, v. 15, n. 1, p. 101-115, 2009.

SILVA, J. M. da. Um passeio pela história dos jardins e um olhar para a criação dos primeiros jardins modernos no Brasil. Revista Espaço Acadêmico, Maringá, v. 13, n. 156, p. 113-126, 2014.

SILVA, I. R.; OLIVEIRA, A. T. S.; SILVA, L. B. O.; BAIA, R. S.; CORREA, T. B. C.; MARTINS, W. B. R. Diagnóstico visual e fitossociologia na arborização de praças em Paragominas, Pará. Revista Brasileira de Arborização Urbana, Piracicaba, v. 13, n. 1, p. 01-13, 2018.

TISCHER, J. C.; FORTE, A. R.; MORAES, C. P. Análise qualiquantitativa de indivíduos arbóreos das praças centrais do município de Leme, SP. Revista Brasileira de Arborização Urbana, Piracicaba, v. 9, n. 3, p. 49-64, 2014.

VIEZZER, J.; BIONDI, D.; MARTINI, A.; GRISE, M.M.; SILVA, D. A. da. As linhas projetuais paisagísticas e as áreas das praças de Curitiba-PR. Scientia Plena, Aracajú, v. 12, n. 9, p. 1-9, 2016.

VIEZZER, J.; BIONDI, D.; MARTINI, A.; GRISE, M. M. A vegetação no paisagismo das praças de Curitiba PR. Ciência Florestal, Santa Maria, v. 28, n. 1, p. 369-383, 2018. 